Article

\title{
Does Money Accelerate Faculty Mobility? Survey Findings from 11 Research Universities in China
}

\author{
Jin Liu ${ }^{1}$, Zhaohui Yin ${ }^{2, *}$, Wenjing Lyu ${ }^{3}$ and Songyue Lin ${ }^{1}$ \\ 1 College of Humanities and Social Sciences, Beijing Institute of Technology, Beijing 100000, China; \\ liujinedu@bit.edu.cn (J.L.); Lsy550309@163.com (S.L.) \\ 2 School of Education, Wuhan University, Luojia Hill, Wuhan 430072, China \\ 3 School of Economics and Management, Tsinghua University, Beijing 100081, China; \\ lvwj.14@sem.tsinghua.edu.cn \\ * Correspondence: yinzhaohui0515@163.com
}

Received: 18 October 2019; Accepted: 28 November 2019; Published: 5 December 2019

check for updates

\begin{abstract}
In the context of global innovation systems, it has become a universal law that the resource elements of scientific and technological innovation, such as talents, flow along the track of high efficiency to the regions that can produce high benefits. As faculty in research universities are important resources of scientific and technological innovation, developing countries such as China have sought to accelerate the transnational mobility of faculty by leveraging income. This study endeavors to gain a better understanding of the motivations for and the outcomes of faculty mobility at Chinese research universities and to determine whether attaining higher income levels through academic mobility can be considered a lever for facilitating change and improving the status of the academic profession in China. Using survey data from 445 faculty members at 11 major research universities in China, this study found a significant relationship between mobility frequency and indirect income. The findings also revealed, however that employees' different attitudes toward income during the process of mobility are a key variable in confirming academic professional boundaries. The findings suggest that more successful mechanisms to attract or retain talented scholars should be developed and that these mechanisms should not focus exclusively on income.
\end{abstract}

Keywords: global innovation systems; Chinese research university; faculty income; academic mobility; academic labor market; ordinary labor market

\section{Introduction}

In today's globalized world, with the closer economic and technological links between countries, the original barriers have been continuously broken, and the mobility of innovative resources such as talents, technology, and capital has continued to increase. Faculty members have the option to transfer between universities and across working sectors. They may consider moving from one institution to another or to a working environment outside the education sector for a variety of reasons, including intellectual collaborations with other scholars [1], better working conditions [2,3], better facilities [4], more scientific output [5], and family reasons [6,7]. Job mobility for faculty can produce a number of positive outcomes, including an increase in productivity [8], new knowledge, and reported satisfaction [9-11].

However, a limited number of studies have focused on the influence of money on faculty mobility. Will faculty members choose to move because of high income (Is money the key factor that influences faculty mobility?)? Does income in China increase following a move compared to countries with mature academic labor markets, such as the U.S. and European countries? We know little about experiences 
with and motivations for mobility among faculty from countries in which the academic profession is undergoing dramatic alterations in terms of emerging or changing academic labor markets.

Mindful of the facets of the "pull-push" phenomenon [12], this study endeavors to gain a better understanding of the motivations for and the outcomes of faculty mobility at Chinese research universities and to determine whether attaining higher income levels through academic mobility can be considered a lever for facilitating change and improving the status of the academic profession in China. Using responses received from the Survey of Faculty Mobility, which was carried out by the Changing Academic Profession project team from mainland China (http://www.hse.ru/en/org/hse/ cinst/academic_profession_eng), this study examines factors that influence faculty mobility at 11 major Chinese universities. This study seeks to resolve three main questions: 1) Does job mobility result in changes to income? 2) What factors, such as academic output, working environment and professional satisfaction, contribute to mobility? 3) Is the relation between faculty mobility and income correlated with gender, academic titles, qualification, experience abroad, or discipline?

Related to the main research questions, this study also endeavors to determine the types of academic institutions and faculties that benefit most from mobility. In China, the frequency of faculty mobility is currently somewhat low; however, the development of globalized education may encourage greater interest in moving to another academic institution and/or to employment outside academe. More comprehensive investigation of the role of faculty mobility is of great significance for improving the environment of the academic profession, promoting job satisfaction and facilitating the management of faculty in higher education institutions (HEIs).

\section{Literature Review}

Faculty mobility has become a barometer for the development of HEIs, and a lack of job mobility due to constricted labor markets, which could affect income, may not reflect the actual competence of faculty members [13]. Today, the academic profession is price-negotiable, and income affects mobility to a large extent among academic institutions and between the academic profession and other fields.

\subsection{Income: An Important but Not Essential Factor}

In certain countries, the income levels of academic faculty make it difficult for them to maintain a middle-class lifestyle, which renders the academic profession a marginal occupation. While recent studies of the academic profession have found that the impact of income on faculty mobility is important and is accompanied by conditions that may offset the detrimental effects, a number of factors can influence faculty mobility, including income, research resources, institutional prestige, academic cooperation between faculty members, university geographic location, and citizenship. While income and opportunity for promotion play crucial roles, other factors are also important. In a review of the 44 reasons for faculty mobility at the University of Michigan, Moore (1998) found that income ranked fifth, below research grants, research opportunities, departmental reputation, and institutional or departmental leadership.

Income is an important indication of one's satisfaction with the working environment and has considerable influence on mobility [14-16], seeking to negotiate better pay and/or research facilities in another institution. Schools where teachers rated their working conditions as more satisfactory had lower attrition rates and also were schools with higher rates of low-income and/or minority students [17]. Further, lower salaries for academic positions may encourage faculty to transition away from the academic profession. As observed in the responses to the U.S. Survey of Doctorate Recipients, salaries are approximately $20 \%$ lower in the education sector than in the business and industry sectors in the U.S. [18]. Additionally, foreign-born, non-native citizens who are highly productive in research and have held appointments for a short period of time are more likely to leave academe and transition to industry [12]. Faculty members who have close contact with industry are more likely to leave the academic profession. In some cases, the move to industry occurs full-time, while it may be part-time in other cases. In the biotechnology field for example, faculty members 
prefer to job-hop among biotechnology companies. Fearful of a large exodus, Harvard eliminated its restriction on the commercialization of biotechnology research to avoid losing its best biology scholars to biotechnology companies.

A recent study [19] found that faculty who chose not to move reported satisfaction with the time available for research and expressed stronger organizational commitment. Those who were dissatisfied with the fairness of work evaluations and who believed tenure decisions were not merit-based were more likely to leave. Some researchers explain that the basic difference between the academic and ordinary labor markets lies in employees' different attitudes toward income [20]. In the academic labor market, faculty members pay greater attention to academic accumulation, new discoveries, innovation, and academic dissemination. Therefore, in the process of moving, scholars focus on academic elements such as academic production, institutional prestige and academic title.

\subsection{Direct and Indirect Income}

Prior research [21] identified four types of indicators of direct faculty income before and after job mobility: annual salary from one's HEI; other income from one's HEI; income from other academic institutions; and income from other employers. In addition, there are three indicators of indirect income [22]: research funds (which can be divided into vertical research and lateral research, with the former mainly from government agencies and the latter from industry); housing (because job negotiations often include this item); and spouse's income (because academic mobility is, to a great extent, not a personal but a family decision, or it is at least greatly affected by family).

\subsection{Correlations Between Faculty Mobility and Faculty Prestige and Performance}

Scholars are keen to assess the impact of institutional prestige and academic performance on faculty mobility. Although there are certainly differences in the conclusions found in the literature, the mainstream view asserts that institutional prestige is more influential for position access and mobility than academic performance. For example, Caplow's [23] study of the mobility of liberal arts faculty found that during the mobility process, institutional prestige was more important than one's previous academic performance. Similarly, in the research of "Global inequality in the academic system", Gerhards [24] concluded that universities' symbolic capital seems to be more important than the quality of a department.

\subsection{Correlation Between Faculty Mobility and Gender}

In general, previous studies have found that female faculty members are less likely to move than their male peers $[25,26]$ because of family caretaking considerations or a preference for larger metropolitan areas [27]. Additionally, some female faculty members may prefer to be affiliated with an institution with higher prestige [28] and may opt to accept a part-time position at a higher prestige institution rather than a full-time appointment at a lower prestige institution. Kacey Beddoes and Alice L. Pawley [29] held that a married woman may be constrained by family responsibility and her husband's career, and the final decision regarding a move is often based on benefit to the husband [30]. In addition to, Jöns' study [31] "transitional academic mobility and gender" with the visiting researchers in Germany found that the academic world of female researchers had less interest in mobility than that of their male colleagues. The limitation of female mobility in their work life found in the literature related to both education and research is family-concerning responsibility especially taking care of their children [32]. Similarly, in the Italian labor market, Alkadry and Tower [33] address an overlooked manifestation of pay discrimination against women in the labor market, and men's salaries increase faster than women's, which is more significant for employee mobility between companies and represents a form of gender salary punishment. Gender bias related to income and mobility is generally similar in the U.S. and Europe. 


\subsection{Study of the Impact Factors for Faculty Mobility in Different Countries}

The literature on the impact factors for faculty mobility has significant national characteristics [34]. The existing literature has noted many concerns about faculty mobility in the U.S. Meanwhile, scholars from other parts of the world have also had many discussions about the impact factors for faculty mobility. Compared with the U.S., European scholars have focused more on the macro and meso levels in recent years, especially the study of how faculty mobility is influenced by various policy designs [35] in which money is the key factor that facilitates scholars' mobility. Some European scholars even believe that the European academic labor market is far from being fully developed and that appropriate policy intervention is thus necessary. Some European countries fully consider the influence of money when designing policies to facilitate mobility (e.g., Sweden), and some non-European countries tend to welcome and promote faculty mobility and incorporate the basic concept of leveraging money to promote faculty mobility in their policy design (e.g., Brazil, Chile, and South Africa).

There has been a general lack of research on job mobility among Chinese faculty members [19], particularly empirical research, and the findings of previous studies have not been consistent with respect to the relationship between income and mobility. In 2008, a questionnaire survey of 268 faculty members at six Chinese universities found that material aspects such as income and preferential treatment were the key factors for promoting faculty mobility [36]. By contrast, in 2012, an analysis of sample data for full-time faculty members at Chinese public four-year universities found that job satisfaction was the most significant variable in explaining faculty mobility intention [37].

\section{Data and Method}

\section{Description of the Data}

Ethical approval for this study was not sought due to the absence of an Ethics Committee process. The following steps were undertaken to ensure due consideration of the ethical process: All participants were provided with written information about the nature and purpose of the research project. Faculties were informed about the study at the beginning that data collected may be included in publications, and that they could withdraw their contributions at any time without penalty. All institutional information was de-identified; all faculty responses were anonymous; faculties were given the choice to respond to the survey questionnaire. Their submission of the questionnaire was taken as indication of their informed consent to participate in the research.

The Survey of Faculty Mobility was distributed to 1,100 faculty members from 11 Chinese research universities. All the included universities are part of the "Double first-class construction" project ("Double first-class construction" project: In 2017, the Chinese government introduced the project to establish world-class universities and world-class disciplines; to date, 42 universities have been in the list of world-class construction universities, 99 universities have been in the list of world-class disciplines construction universities). There were three primary considerations when selecting this sample. The first was the geographic distribution and characteristics of the included universities: four in east China (Peking University, Tsinghua University, Fudan University, and Shanghai Jiao Tong University), three in central China (Wuhan University, Huazhong University of Science and Technology and Central South University), and four in west China (Lanzhou University, University of Electronic Science and Technology of China, Northwestern Polytechnical University, and Northwest Agriculture and Forest University). The second consideration was the universities' rankings: the selected 11 universities are ranked in the top 50 Chinese Universities [38]. The third consideration was the academic disciplines of the universities. Of the 11 universities, five are comprehensive universities, five are polytechnic universities, and one is an agricultural university, which corresponds to the general proportion of comprehensive universities $(33 \%)$, polytechnic universities $(36 \%)$, and agricultural universities (5\%) among Chinese research universities. Overall, the 11 selected universities represent $28 \%$ of the total number (39) of Chinese research universities; thus, the sample can represent the general characteristics of faculty mobility at the main research universities in China (but it cannot represent 
the characteristics of some research universities associated with a specific industry, such as the Ocean University of China).

Survey research on faculty mobility generally focuses on a single discipline $[39,40]$ or several disciplines [41,42], and the sample sizes of these studies are often small-between 100 and 400 subjects-because many potentially mobile faculty members are busy elite scholars $[40,43]$. The disciplines offered by Chinese universities are traditionally divided into five categories, including science, engineering, agronomy, medicine, and liberal arts [44]. Not all research universities have fully established these five disciplines, however. Therefore, in accordance with typical practice in Chinese academic circles [45-47], the sampling method in the present study involved conducting questionnaire surveys of faculty members from all five disciplines at the universities that have fully established those disciplines. In the universities with three or four of the five disciplines, the questionnaire survey was administered only to faculty in the corresponding established disciplines. For example, the University of Electronic Science and Technology of China does not offer medicine and agronomy disciplines, so the sample for that university included only three categories.

The survey consisted of two phases. The goal was to obtain 250 completed questionnaires from faculty members with job mobility experience and to obtain completed questionnaires from a certain proportion of faculty members without job mobility experience, which could serve as a reference sample. The time span for phase 1 was October 2011 to December 2011, during which the questionnaire surveys were administered to and completed by faculty members at Peking University, Tsinghua University, Fudan University, Shanghai Jiaotong University, Huazhong University of Science and Technology, Wuhan University, and the University of Electronic Science and Technology of China. One responsible person in the department of personnel in each university was selected as a contact person to distribute the questionnaires. The proportion of faculty members with job mobility experience in the sample was intentionally increased during the survey phase based on the low response rate [48]. A total of 100 questionnaires were administered at each university, and the proportion of faculty members with job mobility experience was $70-80 \%$, while the proportion of those without mobility experience was $20-30 \%$. A total of 700 questionnaires were disseminated during phase 1 , and 302 valid questionnaires were collected, including 166 from faculty members with the mobility experience. Because the goal (250 questionnaires from faculty with mobility experience) was not reached during phase 1, a second phase was conducted at four universities from October 2012 to February 2013. Of the 1100 total questionnaires distributed, valid responses were received from 445 faculty members, for a response rate of $40.5 \%$. The sample frame and distribution of respondent characteristics are presented in Table 1 . Of the 445 respondents, $59.6 \%$ had mobility experience, and of those with mobility experience, most had only one experience $(56.9 \%)$, most were men $(76.3 \%)$ and most were full professors (51.3\%).

Table 1. Sample frame of faculty mobility survey at Chinese research universities.

\begin{tabular}{|c|c|c|c|c|c|}
\hline \multicolumn{2}{|c|}{ Total sample } & \multirow[t]{2}{*}{$=445$} & \multirow{4}{*}{ Title } & \multirow{2}{*}{$\begin{array}{l}\text { Professor } \\
\text { Associate } \\
\text { professor }\end{array}$} & $\begin{array}{l}40.2 \% \\
51.3 \%\end{array}$ \\
\hline & & & & & $\begin{array}{l}36.3 \% \\
37.1 \%\end{array}$ \\
\hline \multirow{2}{*}{ Gender } & Male & $\begin{array}{l}73.3 \% \\
76.3 \%\end{array}$ & & $\begin{array}{l}\text { Assistant } \\
\text { professor }\end{array}$ & $\begin{array}{l}1.1 \% \\
0.4 \%\end{array}$ \\
\hline & Female & $\begin{array}{l}26.7 \% \\
22.8 \%\end{array}$ & & Lecturer & $\begin{array}{l}19.1 \% \\
10.3 \%\end{array}$ \\
\hline \multirow{2}{*}{$\begin{array}{l}\text { Mobility } \\
\text { experience }\end{array}$} & Yes & $59.6 \%$ & & $\begin{array}{l}\text { Teaching } \\
\text { assistant }\end{array}$ & $\begin{array}{c}1.4 \% \\
0\end{array}$ \\
\hline & No & $40.4 \%$ & & Other & $\begin{array}{l}1.8 \% \\
0.9 \%\end{array}$ \\
\hline
\end{tabular}


In this study, faculty mobility is generally divided into three categories. The first is long-term mobility, which refers the occurrence of a substantive employment relationship, such as changing academic jobs. The second is periodic short-term mobility [49]. The third category is conventional periodic short-term mobility, such as flying faculty [50]. The first type of mobility is very different from the other two, and although many scholars contend that long-term mobility can generate knowledge transfer, it is generally a zero-sum game. However, some scholars assert that the key benefit of long-term mobility is constructing research networks [51]. The influence of mobility is reflected not only in the zero-sum game between brain drain and brain gain but also in the way that brain circulation is managed and promoted [52]. Therefore, this paper focuses on long-term mobility. The survey defined mobility as four main types of substantive moves in the past ten years: 1) a move from an overseas academic institution (university, research institution or enterprise) to a Chinese HEI; 2) a move from another Chinese HEI to the respondent's current HEI; 3) a move from another research institution (mainly the Chinese Academy of Sciences and the Chinese Academy of Social Sciences) to the respondent's current research institution; and 4) a move from a non-research institution (mainly government and finance-supported institutions) to the respondent's current institution.

The items were designed based on the literature on academic mobility and included 27 questions that addressed the respondents' experiences with mobility, changes in income, and satisfaction with income. The questionnaire used in this study covered three types of factors that may affect faculty mobility: twelve personal and family factors (total personal income, potential income and insurance benefits, housing size, personal professional development opportunities, academic titles, workload and work pressure, spouse's workplace, spouse's total income, spouse's career development opportunities, distance from relatives and friends, educational opportunities and environment for offspring, and elder care); nine academic institutional factors (prestige of colleges and departments, cooperation and relationship with colleagues, total research funds, research equipment and library facilities, extent of connection with academic circle, educational ideas and culture, atmosphere of academic freedom, quality of student source, and academic systems and policies); and six social factors (university geographic location, climate of university geographic location, whether the university is located in a metropolis or not, social atmosphere in the location of the university, recreational and leisure facilities in the community, and educational facilities in the community).

\section{Results}

\subsection{Income Change Following a Move}

When comparing faculty members with a previous record of mobility with those who were never mobile, direct income was relatively similar; however, the indirect income of those who were immobile was much lower than that of the mobile faculty members. The results reveal that marked income changes occur for faculty members following a move, but unlike mobility in the industry sector, academic mobility leads to a decrease in faculty members' direct income. The findings presented in Table 2 indicate that for faculty members with mobility experience, a significant change in income occurred after their most recent move, with indirect income increasing and direct income decreasing.

Direct income. According to the survey responses, the total amount of the four direct income sources declined from $¥ 170,000$ (approximately 26,282 US dollars) to $¥ 133,000$ (\$20,563). Overall, after a move, the salary received from the respondent’s HEI decreased by an average of $¥ 36,000$ (\$5566), followed by decreases in income from other employers (down by $¥ 9000$ or $\$ 1391$ ) and other academic institutions (down by $¥ 1000$ or $\$ 155$ ). Only one item rose sharply: other income earned from the HEI (increased by $¥ 9000$ or $\$ 1391$ ). The decrease in salary is due to the scholars' return to China from the U.S. or from European countries where their incomes were higher. On average, the incomes of Chinese scholars who returned from the U.S. decreased by $¥ 161,923(\$ 25,033)$. 
Table 2. Percent change in income indicators resulting from the mobility of faculty members at Chinese research universities.

\begin{tabular}{|c|c|c|c|c|c|c|c|c|c|c|}
\hline & \multicolumn{4}{|c|}{ Direct Income } & \multicolumn{4}{|c|}{ Indirect Income } & \multirow[b]{2}{*}{$\begin{array}{c}\text { Family's } \\
\text { Total } \\
\text { Income }\end{array}$} & \multirow[b]{2}{*}{$\begin{array}{c}\text { Family's } \\
\text { Total } \\
\text { Expenses }\end{array}$} \\
\hline & $\begin{array}{c}\text { Salary from } \\
\text { HEI } \\
(10,000 R M B)\end{array}$ & $\begin{array}{c}\text { Other } \\
\text { Income } \\
\text { From HEI }\end{array}$ & $\begin{array}{l}\text { Income from } \\
\text { other Academic } \\
\text { Institutions }\end{array}$ & $\begin{array}{l}\text { Income } \\
\text { from other } \\
\text { Employers }\end{array}$ & $\begin{array}{l}\text { Total } \\
\text { Research } \\
\text { Funds }\end{array}$ & $\begin{array}{c}\text { Total Lateral } \\
\text { Research Funds }\end{array}$ & $\begin{array}{c}\text { Spouse's } \\
\text { Total } \\
\text { Income }\end{array}$ & $\begin{array}{c}\text { Housing } \\
\text { Size (Sq M) }\end{array}$ & & \\
\hline $\mathrm{BM}^{*}$ & 13.1 & 1.5 & 0.6 & 1.8 & 18.3 & 11.1 & 8.5 & 113 & 24.1 & 11.5 \\
\hline $\mathrm{AM}$ & 9.5 & 2.4 & 0.5 & 0.9 & 27.4 & 12.4 & 14.6 & 114.6 & 19.8 & 10.5 \\
\hline NM & 11.1 & 3.7 & 0.3 & 5 & 2.9 & 1.1 & 4.5 & 101.3 & 13.7 & 4.7 \\
\hline AM-BM & -3.6 & 0.9 & -0.1 & -0.9 & 9.1 & 1.3 & 6.1 & 1.6 & -4.3 & -1 \\
\hline AM-NM & -1.6 & -1.3 & 0.2 & -4.1 & 24.5 & 11.3 & 10.1 & 13.3 & 6.1 & 5.8 \\
\hline BM-NM & 2 & -2.2 & 0.3 & -3.2 & 15.4 & 10 & 4 & 11.7 & 10.4 & 6.8 \\
\hline
\end{tabular}


Indirect income. Regarding the most recent move of faculty members with mobility experience, the amount of research funds received exhibited a dramatic 50\% increase, from an annual average salary of $¥ 183,000(\$ 28,293)$ to $¥ 274,000(\$ 42,362)$. Vertical research funds primarily contributed to this increase. Vertical funds increased by $108 \%$, while lateral funds increased by only $12 \%$. In addition, the respondents reported a $72 \%$ increase in their spouses' total income, from an annual average of $¥ 85,000(\$ 13,141)$ to $¥ 146,000(\$ 22,572)$, and housing size also increased (although the increase was only approximately 1.6 square meters).

\subsection{Relativity Analysis of Income and Faculty Mobility}

As noted in Table 2, changes related to mobility were observed for both direct and indirect income. Does this mean that a relationship exists between income and faculty mobility? Further analysis suggested that direct income was positively associated $(r=0.198, p=0.023)$ with the moving or not variable, and indirect income via total research funds had a significant positive correlation $(r=0.223$, $p=0.004)$ with moving or not. Neither university geographic location $(r=0.098, p=0.407)$ nor spouse's total income $(r=0.198, p=0.023)$ was significantly associated with mobility. While spouse's total income was positively correlated with moving for female respondents $(r=0.086, p=0.269)$, a similar correlation for male faculty $(r=0.287, p=0.015)$ with mobility experience was not significant. This finding indicates that gender plays a special role in the relationship between income and mobility. The most likely reason is that a male's income is typically higher than his spouse's income. Spouses continue to maintain their salary levels following a move, a result that is consistent with some research on gender, family and faculty mobility $[25,53]$.

Additional analyses revealed that mobility was positively correlated with indirect income. Additionally, mobility frequency was positively correlated with two of the indirect income indicators $(r=0.372, p<0.001)$ - total research funds $(r=0.536, p=0.002)$ and spouse's total income $(r=0.278$, $p=0.002$ - but was not significantly correlated with the university's geographic location $(p=0.220)$. These findings indicate that the mobility of faculty members at Chinese research universities significantly increases their indirect income, which may explain why some of these faculty members continue to pursue academic mobility regardless of decreases in their direct income.

Subsequent analyses employed two demographic indicators, gender and age, as control variables to perform partial correlation analysis. As noted in Table 3, gender did not make a difference in the relativity level between income (direct and indirect) and both moving or not and mobility frequency. However, when age was introduced, the correlation level between income (direct and indirect income) and moving or not disappeared. A significant positive correlation was observed only between current direct income and mobility frequency. Additionally, the correlation between mobility frequency and spouse's total income became non-significant when age was considered. This may indicate that when excluding the influence of age, a linear relationship between mobility frequency and direct income can be observed. However, when age is considered, the linear relationship between mobility and income disappears, and there is no relationship between mobility frequency and indirect income.

Table 3. Partial correlation matrix.

\begin{tabular}{cccccc}
\hline & Direct Income & $\begin{array}{c}\text { Total Research } \\
\text { Funds }\end{array}$ & Housing Size & $\begin{array}{c}\text { Spouse's Total } \\
\text { Income }\end{array}$ \\
\hline \multirow{3}{*}{ Moving or not } & No control & $0.328^{* * *}$ & $0.344^{* * *}$ & -0.075 & $0.153^{*}$ \\
& Control gender & $0.176^{*}$ & $0.176^{*}$ & 0.027 & 0.080 \\
& Control gender, age & 0.010 & 0.065 & 0.006 & 0.081 \\
\hline \multirow{2}{*}{ Mobility } & No control & $0.372^{* * *}$ & $0.388^{* * *}$ & 0.149 & $0.259^{* * *}$ \\
frequency & Control gender & $0.363^{* * *}$ & $0.352^{* * *}$ & 0.138 & $0.265^{* * *}$ \\
& Control gender, age & $0.195^{*}$ & $0.268^{* * *}$ & 0.112 & 0.124 \\
\hline \multicolumn{2}{c}{ Levels: ${ }^{* * *} p<0.001^{* *} p<0.01,^{*} p<0.05}$.
\end{tabular}




\subsection{Importance and Priority Ranking of Faculty Mobility}

As revealed in Table 4, the overall responses to the 27 items $(1=$ very important; $2=$ important; $\geq 3$ = not important) offer insight into the issues that influence decisions related to mobility. Both faculty groups ranked atmosphere of academic freedom, academic systems and policies, and quality of student source as important. Faculty members with mobility experience reported that university location and spouse's career development opportunities had a greater impact on their academic mobility than faculty members without mobility experience. It is worth noting that the faculty members, regardless of their experience with mobility, indicated that direct income and indirect income had little effect on their academic mobility.

Table 4. Mean score and rank of mobility impact factors.

\begin{tabular}{|c|c|c|c|c|c|}
\hline Move Occurred & $\begin{array}{l}\text { Importance } \\
\text { (Mean) }\end{array}$ & Rank & Did Not Move & $\begin{array}{l}\text { Importance } \\
\text { (Mean) }\end{array}$ & Rank \\
\hline $\begin{array}{l}\text { Personal growth } \\
\text { opportunity }\end{array}$ & 1.61 & 1 & $\begin{array}{c}\text { Personal growth } \\
\text { opportunity }\end{array}$ & 1.603 & 1 \\
\hline $\begin{array}{l}\text { Atmosphere of academic } \\
\text { freedom }\end{array}$ & 1.873 & 2 & $\begin{array}{l}\text { Educational opportunity } \\
\text { and environment for } \\
\text { offspring }\end{array}$ & 1.739 & 2 \\
\hline $\begin{array}{l}\text { Extent of connection } \\
\text { with academic circle }\end{array}$ & 1.874 & 3 & Spouse's workplace & 1.788 & 3 \\
\hline $\begin{array}{l}\text { Educational opportunity } \\
\text { and environment for } \\
\text { offspring }\end{array}$ & 1.894 & 4 & $\begin{array}{l}\text { Extent of connection } \\
\text { with academic circle }\end{array}$ & 1.797 & 4 \\
\hline $\begin{array}{c}\text { Academic systems and } \\
\text { policies }\end{array}$ & 1.901 & 5 & $\begin{array}{l}\text { Cooperation or } \\
\text { relationship with } \\
\text { colleagues }\end{array}$ & 1.8 & 5 \\
\hline $\begin{array}{l}\text { Prestige of colleges and } \\
\text { departments }\end{array}$ & 1.917 & 6 & $\begin{array}{l}\text { Research equipment and } \\
\text { library facilities }\end{array}$ & 1.8 & 6 \\
\hline $\begin{array}{c}\text { Educational ideas and } \\
\text { culture }\end{array}$ & 1.941 & 7 & $\begin{array}{l}\text { Academic systems and } \\
\text { policies }\end{array}$ & 1.818 & 7 \\
\hline Quality of student source & 1.949 & 8 & $\begin{array}{l}\text { Atmosphere of academic } \\
\text { freedom }\end{array}$ & 1.833 & 8 \\
\hline $\begin{array}{l}\text { Total research funds } \\
\text { Cooperation or }\end{array}$ & 1.958 & 9 & Total research funds & 1.844 & 9 \\
\hline $\begin{array}{l}\text { relationship with } \\
\text { colleagues }\end{array}$ & 1.992 & 10 & Educational facilities & 1.855 & 10 \\
\hline
\end{tabular}

\subsection{The Importance of Factors Before and After a Move}

Table 5 presents the level of importance for select factors before and after a move $(1=$ Became very wealthy after move; $5=$ Became very poor after move). Personal professional development opportunities remained the most highly ranked item following a move. This result appears to illustrate that activities beneficial to one's intellectual and career development take high priority, regardless of the need for relocation. Some of the other items did not change in terms of priority order following a move, including atmosphere of academic freedom, cooperation and relationship with colleagues, social atmosphere, and workload and work pressure. The consistency in the ranking of these items appears to indicate that mobility decisions are made in a manner that ensures similar environments and expectations for work. However, some items were reported to be of greater importance following a move, such as total research funds, research equipment and library facilities, educational facilities in the community, recreational and leisure facilities in the community, and academic titles. The result is not surprising, and there is no doubt that the key factors for attracting talented scholars are academic titles, research funds, and research facilities. 
Table 5. Ranking of impact for items related to mobility vs. amplitude of variation after mobility.

\begin{tabular}{|c|c|c|c|}
\hline $\begin{array}{l}\text { Impact Factors for Mobility } \\
\text { (Change) }\end{array}$ & $\begin{array}{c}\text { A1 Rank of Impact } \\
\text { Factors for Mobility by } \\
\text { Faculty Self-Evaluation }\end{array}$ & $\begin{array}{l}\text { A2 Rank of Impact } \\
\text { Factor after Move }\end{array}$ & Change \\
\hline $\begin{array}{c}\text { Personal professional development } \\
\text { opportunities }\end{array}$ & 1 & 1 & 0 \\
\hline Atmosphere of academic freedom & 2 & 6 & -4 \\
\hline $\begin{array}{l}\text { Extent of connection with academic } \\
\text { circle }\end{array}$ & 3 & 2 & 1 \\
\hline $\begin{array}{l}\text { Educational opportunities and } \\
\text { environment for offspring }\end{array}$ & 4 & 7 & -3 \\
\hline Academic systems and policies & 5 & 7 & -8 \\
\hline Prestige of colleges and departments & 6 & 3 & 3 \\
\hline Educational ideas and culture & 7 & 9 & -2 \\
\hline Quality of student source & 8 & 4 & 4 \\
\hline Total research funds & 9 & 5 & 4 \\
\hline $\begin{array}{c}\text { Cooperation and relationship with } \\
\text { colleagues }\end{array}$ & 10 & 14 & -4 \\
\hline Social atmosphere & 11 & 15 & -4 \\
\hline Spouse's workplace & 12 & 17 & -5 \\
\hline $\begin{array}{l}\text { Research equipment and library } \\
\text { facilities }\end{array}$ & 13 & 8 & 5 \\
\hline Academic titles & 14 & 11 & 3 \\
\hline University geographic location & 15 & 10 & 5 \\
\hline Elder care & 16 & 21 & -5 \\
\hline Housing area & 17 & 23 & -6 \\
\hline Personal total income & 18 & 24 & -6 \\
\hline $\begin{array}{c}\text { Potential income and Insurance } \\
\text { benefits }\end{array}$ & 19 & 22 & -3 \\
\hline Educational facilities & 20 & 12 & 8 \\
\hline $\begin{array}{c}\text { Career development opportunities } \\
\text { of spouse }\end{array}$ & 21 & 20 & 1 \\
\hline Workload and working pressure & 22 & 27 & -5 \\
\hline $\begin{array}{c}\text { Climate of university geographic } \\
\text { location }\end{array}$ & 23 & 18 & 5 \\
\hline Metropolis or not & 24 & 16 & 8 \\
\hline Spouse's total income & 25 & 25 & 0 \\
\hline Distance from relatives and friends & 26 & 25 & 0 \\
\hline Recreational and leisure facilities & 27 & 19 & 8 \\
\hline
\end{tabular}

\subsection{Principal Component Analysis}

A principal component analysis (PCA) of the 20 impact factors was performed to group similar items into subgroups for data reduction, the results are shown in Table 6. It can be seen that the measured value of the sample data KMO (Kaiser-Meyer-Olkin Measure of Sampling Adequacy) was 0.802, The Barlett sphericity test was $1936.29(p<0.01)$, indicating the suitability for PCA. The PCA resulted in five factors with Eigen-values greater than 1.0 and explained $62 \%$ of the total variation. The Cronbach's alpha reliability scores for the five components ranged from 0.725 to 0.809 .

The five components were as follows:

Component 1 (departmental influence): four items—atmosphere of academic freedom, educational ideas and culture, academic systems and policies, and quality of student source.

Component 2 (research environment): five items—-total research funds, prestige of colleges and departments, research equipment and library facilities, cooperation and relationship with colleagues, and extent of connection with academic circle.

Component 3 (geographic location and social atmosphere): five items-university geographic location, climate of university geographic location, social atmosphere, recreational and leisure facilities in the community, and educational facilities in the community. 
Component 4 (income): three items-total personal income, potential income and insurance benefits, and housing size.

Component 5 (spouse): three items—spouse's career development opportunities, spouse's workplace, and spouse's total income.

Table 6. Principal component analysis.

\begin{tabular}{ccc}
\hline & Component Loadings & Internal Consistency (Alpha) \\
\hline Departmental Influence & & 0.809 \\
Atmosphere of academic freedom & 0.794 & \\
Educational ideas and culture & 0.794 & \\
Academic systems and policies & 0.710 & 0.775 \\
Quality of student source & 0.626 & \\
\hline Research Environment & & \\
Total research funds & 0.769 & \\
Prestige of colleges and departments & 0.703 & \\
Research equipment and library facilities & 0.700 & \\
Cooperation and relationship with colleagues & 0.559 & \\
Extent of connection with academic circle & 0.543 & \\
\hline Geographic location and social atmosphere & & \\
Climate of university location & 0.805 & 0.788 \\
University location & 0.781 & \\
Social atmosphere & 0.696 & \\
Recreational and leisure facilities & 0.681 & \\
Educational facilities & 0.465 & \\
Income & & \\
Total personal income & 0.870 & \\
Housing size & 0.841 & \\
Spouse & 0.714 & \\
\hline Potential income and insurance benefits & 0.881 & \\
Spouse's career development opportunities & 0.836 & \\
Spouse's total income & 0.712 & \\
\hline
\end{tabular}

4.6. Analysis of Faculty Mobility Impact Factors: Relationships between Income and Performance, Prestige and Academic Title

Because of its strong correlation with income, we chose mobility frequency as the dependent variable for the regression model. Since housing size was not correlated with moving or not or with mobility frequency, it was not included in the model. The independent variables in the model included the income variables as well as academic titles and prestige of colleges and departments.

As noted in Table 7, a stepwise analysis was employed to assess the additive effects of the variables. The final model has good explanatory power (R-square $=0.698)$, indicating that the selected variables explain faculty mobility. Overall, the factors related to performance, income, institutional prestige and academic titles contribute to predicting faculty mobility.

Specifically, considering all publications at home and abroad in the past five years as an indicator of academic performance can demonstrate scholars' academic capability. In the regression model, the relationship between publication quantity and mobility frequency passed the significance level test. The income indicators also had strong explanatory power in this model, especially the direct income indicator, with a value reaching $13.2 \%$, while the total research funds indicator for indirect income was over $10 \%$. Another indirect income indicator, spouse's total income, had weak explanatory power, only $2.4 \%$. This result reveals that in the faculty mobility process at Chinese research universities, income continues to play a very important role, which is reflected not only in scholars' personal income but also in their research funds. It is also partially related to the possession of research resources. As an indicator of the prestige of colleges and departments, types of doctoral degrees granted by the institution contributed significantly to this model. When we ranked the prestige of institutions from 
high to low (based on a scale of 1-4), we found that the lower an institution's rank was, the less often one moved.

Table 7. Regression models of the impact factors at Chinese research universities.

\begin{tabular}{|c|c|c|c|c|c|c|c|c|}
\hline & & (1) & (2) & (3) & (4) & (5) & (6) & (7) \\
\hline \multirow{3}{*}{ Income } & Level of income after move & $0.045^{* * *}$ & $0.028 * *$ & $0.027 * *$ & $0.022 *$ & 0.017 & -0.156 & -0.169 \\
\hline & Income from projects after move & & $0.015^{* * *}$ & $0.016^{* * *}$ & $0.011 * * *$ & $0.016^{* * *}$ & 0.002 & 0.011 \\
\hline & Total income of spouse after move & & & 0.006 & 0.004 & 0.005 & -0.021 & -0.071 \\
\hline $\begin{array}{l}\text { Academic } \\
\text { Titles }\end{array}$ & Academic titles & & & & $-0.345^{* * *}$ & $-0.300^{* * *}$ & -0.141 & -1.714 \\
\hline \multirow[t]{2}{*}{ Prestige } & $\begin{array}{l}\text { Cumulative overseas academic } \\
\text { working time }\end{array}$ & & & & & 0.025 & 0.345 & 0.124 \\
\hline & $\begin{array}{c}\text { Type of doctoral degrees granted } \\
\text { by the institution }\end{array}$ & & & & & & -0.503 & -2.675 \\
\hline Performance & Total number of published papers & & & & & & & -0.013 \\
\hline Adjusted R2 & & 0.132 & 0.246 & 0.270 & 0.374 & 0.412 & 0.349 & 0.698 \\
\hline
\end{tabular}

This study included cumulative academic work time abroad in the regression model. The results indicate that there was a significant positive correlation between the experience of working abroad at academic institutions (regarded as "international reputation") and mobility frequency. The more cumulative time that was spent working abroad in academic institutions, the more times the faculty member moved. Additionally, academic titles also had an important influence on the regression model. With titles ranked from high to low (1 for professor, 5 for teaching assistant), we found that the higher one's title was, the more frequently he or she moved.

The regression models presented in Table 7 indicate that the effects of income on faculty mobility are weaker than the effects of academic performance. It should be noted that types of doctoral degrees granted by the institution not only contributed to the model but also reduced the explanatory power. This model intuitively demonstrates that among faculty members at Chinese research universities, neither direct nor indirect income is the core impact factor, although they play crucial roles in the mobility process.

\section{Discussion}

The findings of this study demonstrate that although income contributes to faculty mobility at major Chinese research universities, a number of additional factors remain important for faculty and their work, particularly for those who move to a different institution. The desire for academic performance and institutional prestige are equal to if not more important than income. In fact, Chinese scholars frequently have discussions about the impact factors for faculty mobility at the theoretical level, but most of the impact factors have not yet been tested, and non-monetary factors are considered key for influencing faculty mobility. The first of these is educational background and "guanxi". The Chinese academic labor market is not yet completely marketized [19,54,55], so positive "guanxi" is needed for some aspects, such as obtaining new job information [56], acquiring help in the mobility process [36] and career development following a move [6,57-59], and these close and even private academic contacts are based primarily on the relationship between supervisors and students as well as self-established relationship networks in academic circles. Another of our studies analyzed the curriculum vitae of faculty members from "211 Project" universities and found that the rate of academic inbreeding at a few research universities (even well-known universities at the top of the Shanghai JiaoTong University Ranking list) is still higher than $60 \%$, so the low mobility rate of Chinese academics is related to academic inbreeding. In contrast, the collapse of or tension in "guanxi" at faculty members' original academic institutions is also important for faculty mobility. For example, an interview about faculty mobility among Chinese scholars suggested that academic organizational culture is a significant factor. Academic organizational culture will undoubtedly generate centrifugal forces if the team disagrees, if there are strains in interpersonal relationships and if team members defame each other [56]. The second factor is academic titles. Some studies $[60,61]$ have asserted that 
the pursuit of senior academic titles provides motivation to transition to a new academic position, but this notion is controversial and has not undergone comprehensive empirical testing. For instance, some studies have found that only a few faculty members transfer to lower-ranked universities because of the pressure of academic titles, while fewer studies have reported that the issue of academic titles is resolved by transferring to lower-ranked universities [62].

\section{Implications}

At present, affected by the international financial crisis, the economies of developed countries have experienced varying degrees of recession. Thus innovative resources are actively seeking development space abroad, and emerging countries such as China have become the main target. The flow of innovation elements is reshaping the global innovation system. China has paid more attention to the issue of faculty mobility, placing great emphasis on faculty income. The findings herein demonstrate that income is one factor for mobility, but it is not the core factor. The strategic plans developed by university officials or governing agencies can partially but not fully achieve their objectives by simply raising income to promote mobility. Additionally, while the income of Chinese academics that return to their native land to work has greatly improved the total income for faculty members remains lower in China than in the U.S. and in European countries. Based on the research, this paper suggests that developing countries should improve the quality of higher education, the reputation of academic institutions, and the working conditions of faculty members and should guarantee academic freedom. Although income is indeed important, these aspects may be more influential than merely raising income. The findings regarding the relationship between income and mobility should be applied to policy practice areas, for example, effective mentoring of junior faculty members, and ample health and retirement benefits should be provided. Such policies may encourage faculty to consider how and when mobility may benefit them.

Author Contributions: Conceptualization, J.L. and Z.Y.; methodology, W.L.; software, W.L.; validation, J.L. and W.L.; formal analysis, J.L.; investigation, Z.Y.; resources, Z.Y.; data curation, Z.Y.; writing—original draft preparation, J.L.; writing - review and editing, S.L.; visualization, S.L.; supervision, S.L.; project administration, W.L.

Funding: This research received no external funding.

Conflicts of Interest: The authors declare no conflict of interest.

\section{References}

1. Ynalvez, M.C.; Shrum, W.M. International graduate science training and scientific collaboration. Int. Sociol. 2009, 24, 870-901. [CrossRef]

2. Johnsrud, L.K.; Heck, R.H.; Rosser, V.J. Morale matters: Administrations and their Intent to leave. J. High. Educ. 2000, 71, 34-59.

3. Rosser, V.J. Faculty members' intentions to leave: A national study on their work life and satisfaction. Res. High. Educ. 2004, 45, 285-309. [CrossRef]

4. $\mathrm{Xu}$, Y.J. Faculty turnover: Discipline-specific attention is warranted. Res. High. Educ. 2008, 49, 40-61. [CrossRef]

5. Ackers, L. Internationalization, mobility, and metrics: A new form of indirect discrimination? Minerva 2008, 46, 411-435. [CrossRef]

6. Liu, J. An empirical study on social capital and faculty mobility in colleges and universities. Shandong High. Educ. 2016, 4, 75-82.

7. Stewart, P.E. You moved up, did you forget us?: The influence of african american intra-familial social mobility on extended family relationships. J. Afr. Am. Stud. 2015, 19, 214-232. [CrossRef]

8. Horta, H.; Yonezawa, A. Going places: Exploring the impact of intra-sectoral mobility on research productivity and communication behaviors in Japanese academia. Asia Pac. Educ. Rev. 2013, 14, 537-547. [CrossRef]

9. Cruz-Castro, L.; Sanz-Menéndez, L. Mobility versus job stability: Assessing tenure and productivity outcomes. Res. Policy 2010, 39, 27-38. [CrossRef] 
10. OECD. The Global Competition for Talent-Mobility of the Highly Skilled; OECD: Paris, France, 2008.

11. Herrera, L.; Muñoz-Doyague, M.E.; Nieto, M. Mobility of public researchers, scientific knowledge transfer, and the firm's innovation process. J. Bus. Res. 2010, 63, 510-518. [CrossRef]

12. Lawrence, J.; Cells, S.; Kim, H.S.; Lipson, S.; Tong, X. To stay or not to stay: Retention of Asian international faculty in STEM fields. High. Educ. 2014, 67, 511-531. [CrossRef]

13. Bauder, H. The international mobility of academics: A labour market perspective. Int. Migr. 2015, 53, 83-96. [CrossRef]

14. Bense, K. International teacher mobility and migration: A review and synthesis of the current empirical research and literature. Educ. Res. Rev. 2016, 17, 37-49. [CrossRef]

15. Appelt, S.; van Beuzekom, B.; Galindo-Rueda, F.; de Pinho, R. Which factors influence the international mobility of research scientists? In Global Mobility of Research Scientists; Academic Press: San Diego, CA, USA, 2015; pp. 177-213.

16. Lee, J.T.; Kuzhabekova, A. Reverse flow in academic mobility from core to periphery: Motivations of international faculty working in Kazakhstan. High. Educ. 2018, 76, 369-386. [CrossRef]

17. Geiger, T.; Pivovarova, M. The effects of working conditions on teacher retention. Teach. Teach. 2018, 24, 604-625. [CrossRef]

18. Karen, L. Webber Research productivity of foreign- and us-born faculty: Differences by time on task. High. Educ. 2012, 64, 709-729.

19. Liu, J.; Shen, H. On the segmentation of academic labor market. Res. High. Educ. Eng. 2015, 04, 76-81.

20. Liu, J. Faculty Mobility and Academic Labor Market; The Commercial Press: Beijing, China, 2015.

21. Gomez-Mejia, L.R.; Balkin, D.B. Determinants of faculty pay: An agency theory perspective. Acad. Manag. J. 1992, 35, 925-955.

22. Xiong, J.F. The Study on the Compensation Structure of University Teachers. Ph.D. Thesis, Huazhong University of Science and Technology, Wuhan, China, 2014. Unpublished work.

23. Caplow, T.; McGee, R.J. The Academic Marketplace; Basic Books: New York, NY, USA, 1999.

24. Gerhards, J.; Hans, S.; Drewski, D. Global inequality in the academic system: Effects of national and university symbolic capital on international academic mobility. High. Educ. 2018, 76, 669-685. [CrossRef]

25. Keith, K.; McWilliams, A. The wage effects of cumulative job mobility. Ind. Labor Relat. Rev. 1995, 49, $121-137$. [CrossRef]

26. Marwell, G.; Rosenfeld, R.; Spilerman, S. Geographic constraints on women's careers in academia. Science 1979, 205, 1225-1231. [CrossRef] [PubMed]

27. Rosenfeld, R.; Jones, J. Exit and Re-entry in higher education. In Academic Labor Markets and Careers; Breneman, D.W., Youn, T., Eds.; Falmer: New York, NY, USA, 1988; pp. 74-79.

28. O'Meara, K.A.; Bloomgarden, A. The Pursuit of Prestige: The Experience of Institutional Striving from a Faculty Perspective. J. Profr. 2011, 4, 40-73.

29. Beddoes, K.; Pawley, A.L. 'Different people have different priorities': Work-family balance, gender, and the discourse of choice. Stud. High. Educ. 2014, 39, 1573-1585. [CrossRef]

30. Mason, M.A.; Wolfinger, N.H.; Goulden, M. Do Babies Matter? Gender and Family in the Ivory Tower; Rutgers University Press: New Brunswick, NJ, USA, 2013.

31. Jöns, H. Transnational academic mobility and gender. Glob. Soc. Educ. 2011, 9, 183-209. [CrossRef]

32. Prozesky, H.; Beaudry, C. Mobility, Gender and Career Development in Higher Education: Results of a Multi-Country Survey of African Academic Scientists. Soc. Sci. 2019, 8, 188. [CrossRef]

33. Alkadry, M.G.; Tower, L.E. Covert pay discrimination: How authority predicts pay differences between women and men. Public Adm. Rev. 2011, 71,740-750. [CrossRef]

34. Kauppinen, I. Towards transnational academic capitalism. High. Educ. Int. J. High. Educ. Educ. Plan. 2012, 64, 543-556. [CrossRef]

35. Parey, M.; Waldinger, F. Studying abroad and the effect on international labour market mobility: Evidence from the introduction of erasmus. Econ. J. 2011, 121, 194-222. [CrossRef]

36. Guo, L.J. A Survey Study on the Situation of Faculty Mobility in the Reform of Faculty's Employment-Appointment System. Educ. Res. Mon. 2008, 4, 29-31.

37. You, Y. The Intention to Leave: An Empirical Study of Job Satisfaction in Higher Education. Peking Univ. Educ. Rev. 2014, 12, 128-140.

38. Wu, S.L. A Suitable University and Specialty for You; China Statistics Press: Beijing, China, 2011. 
39. Ylijoki, O.H.; Henriksson, L. Tribal, proletarian and entrepreneurial career stories: Junior academics as a case in point. Stud. High. Educ. 2015, 11, 1-17. [CrossRef]

40. Winter, P.A.; Kjorlien, C.L. Community college faculty recruitment: Effects of job mobility, recruiter similarity-dissimilarity, and applicant gender. Community Coll. J. Res. Pract. 2000, 24, 547-566.

41. Emmioğlu, M.A.E. Navigating careers: Perceptions of sciences doctoral students, post-phd researchers and pre-tenure academics. Stud. High. Educ. 2015, 40, 1770-1785.

42. Rui, B. Academic job satisfaction and motivation: Findings from a nationwide study in portuguese higher education. Stud. High. Educ. 2014, 40, 52-65.

43. Svetlik, I.; Lalić, A.B. The impact of the internationalisation of higher education on academic staff development-The case of slovenian public universities. Stud. High. Educ. 2016, 41, 364-380. [CrossRef]

44. Shen, H. Hierarchical Classification of Higher Education Institutions to Meet the Diversified Social Demand. J. High. Educ. 2010, 7, 41-44.

45. Zhang, D.M.; Xie, B.S. Analysis on Knowledge Spillover of R\&D Investment in Universities of Technology, Ariculture and Medicine on Entreprise Technical Innovation. Sci. Res. Manag. 2014, 35, 136-143.

46. Li, Q.X.; Ma, F.C.; Zhang, Q. An Evaluation of the Allocation of Scientific Research Resources at Universities of Science, Engineering, Agriculture and Medicine. Sci. Res. Manag. 2016, 37, 6-10.

47. Guan, H.B.; Wu, D.K. An Empirical Study on Scientific Research Efficiency at Chinese Universities-Based on the Data from 28 Provinces. China Manag. Inf. 2013, 16, 38-42.

48. Sidhu, R.; Yeoh, B.; Chang, S. A situated analysis of global knowledge networks: Capital accumulation strategies of transnationally mobile scientists in Singapore. High. Educ. 2015, 69, 79-101. [CrossRef]

49. Meek, M.J.V.L. Scientific mobility and international research networks: Trends and policy tools for promoting research excellence and capacity building. Stud. High. Educ. 2013, 38, 331-344.

50. Smith, K. Exploring flying faculty teaching experiences: Motivations, challenges and opportunities. Stud. High. Educ. 2014, 39, 1-18. [CrossRef]

51. Turpin, T.; Woolley, R.; Marceau, J.; Hill, S. Conduits of knowledge in the Asia Pacific. Asian Popul. Stud. 2008, 4, 247-265. [CrossRef]

52. Woolley, R.; Turpin, T.; Marceau, J.; Hill, S. Mobility matters: Research training and network building in science. Comp. Technol. Transf. Soc. 2009, 6, 159-184. [CrossRef]

53. Rosenfeld, R.A.; Jones, J. Institutional mobility among academics: The case of psychologists. Sociol. Educ. 1986, 59, 212-226. [CrossRef]

54. Yan, F.Q. On Characteristics of Academic Labor Market and Tenure System of Research Universities. Peking Univ. Educ. Rev. 2005, 3, 64-69.

55. Li, Z.F.; Xie, J.J. Characteristics of Academic Profession's Mobility and Formation of Academic Labor Market. Educ. Rev. 2008, 5, 11-15.

56. Gong, B.; Zhou, H. Analysis of micro system of teacher mobility in university: In the perspective of the sociology of organizations. J. Educ. Stud. 2007, 3, 37-46.

57. Zhang, X.P. Research on Mobility and Growth of Academic Profession. Ph.D. Thesis, East China Normal University, Shanghai, China, 2011. Unpublished work.

58. Wu, Y.X. Social networks, occupational attainment and mobility. Sociol. Stud. 2011, 5, 128-152.

59. Su, L.F.; Meng, D.H. Strong ties or weak ties: The using of college graduates' social capital in employment. J. Huazhong Norm. Univ. (Humanit. Soc. Sci.) 2013, 52, 155-162.

60. Wu, P.Q. Comparative Study of Faculty Mobility between China and Japan. Ph.D. Thesis, Beijing Normal University, Beijing, China, 2009. Unpublished work.

61. Zhang, C. Study on the Problems of Mobility and Stability of Faculty Members. Sci. Technol. West China 2008, 7,89-90.

62. Wu, P.Q.; Feng, H.M. The interschool mobility of academic profession-A comparison between web-based content analysis data and international investigation. Sci. Res. Manag. 2013, 34, 86-92.

(C) 2019 by the authors. Licensee MDPI, Basel, Switzerland. This article is an open access article distributed under the terms and conditions of the Creative Commons Attribution (CC BY) license (http://creativecommons.org/licenses/by/4.0/). 